Journal of Applied Biology \& Biotechnology Vol. 4 (03), pp. 033-040, May-June, 2016

Available online at http://www.jabonline.in

DOI: 10.7324/JABB.2016.40306

(c)) EY-NC-SA

\title{
Ten different brewing methods of green tea: comparative antioxidant study
}

\author{
Naila Safdar*, Amina Sarfaraz, Zehra Kazmi, Azra Yasmin \\ Microbiology and Biotechnology Research Lab, Department of Environmental Sciences, Fatima Jinnah Women University, Rawalpindi, Pakistan.
}

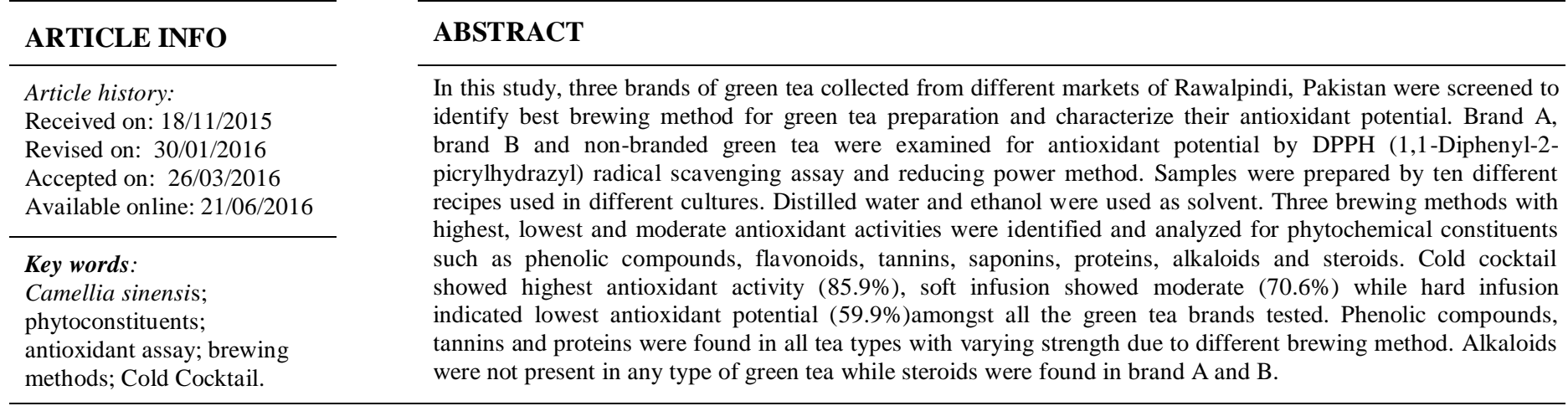

\section{INTRODUCTION}

Tea is the nature's wealth to human. In the world, the second mainly consumed drink is tea, next to water. It is an infusion that is prepared by steeping fermented leaves and twigs of a plant, Camellia sinensis, in water or other solvents [1]. Twigs, buds and leaves of Camellia sinensis are used to generate tea [2]. Camellia sinensis, tea plant is aboriginal to Southeast Asia but now a days it is harvested in approximately more than thirty nations of the world. Shen Nung, a Chinese emperor, discovered tea accidentally in 2737 BC while boiling water and some leaves fell into it, producing an apparent aroma and taste.

Emperor named it as, 'heaven sent'. The variation in the tea aroma, color, name and flavor depends upon how the tea leaves are manufactured [3]. Asia has a great contribution to every green tea importing market in the world. In Japan, consumption of green tea is about 100,000 tons per annum, out of which 90,000 tons are produced domestically. Other green tea

* Corresponding Author

Naila Safdar, Microbiology and Biotechnology Research lab, Department of Environmental Sciences, Fatima Jinnah Women University, Rawalpindi, Pakistan.Email: naila_bch@yahoo.com producing countries are Kenya, Taiwan, Korea, Sri Lanka, India, Vietnam, Bolivia \& Hawaii [4]. Free radicals, which are produced in body by several biochemical reactions, have been concerned as mediators of many diseases, including atherosclerosis, cancer and heart diseases [5]. Antioxidants can efficiently neutralize the free radicals by safely cooperating with free radicals and ceasing the chain reaction before vital molecules get damaged. Antioxidants in blood, tissue and cells play a significant role in neutralizing the typical level of oxidative damage caused by these free radicals. Plants are a prosperous source of polyphenolic compounds which are efficient antioxidants [6].

The main antioxidants in tea are catechins, flavonols, tannins and phenolic compounds. Green tea is the most powerful antioxidant tea among all tea types. The antioxidant properties of green tea polyphenols and the pro oxidant effects of these compounds have been recommended as potential candidates for cancer prevention [7]. The tea plant has shown the antimicrobial efficiency against a variety of pathogenic microorganisms and beneficial effects of tea have been attributed to its strong antioxidant activity which in turn is due to the phenolic compounds [8]. The carotenoids, tocotrienols, flavonoids, cinnamic acid, benzonic acid, ascorbic acid, folic acid, tocopherols are some antioxidants generated by the plants [9]. 
Active constituents of green tea possess many medicinal benefits, theanine has potential role in reducing stress, catechins promote weight loss and has antiviral, anti-inflammatory and anticarcinogenic effects while theaflavins are associated with decreased cardiovascular risk [10].

The side effects of nervous system stimulants and tea may include anxiety, nervousness, and irritation of the gastric mucosa, heart irregularities, tremors, headaches, hypertension, insomnia, restlessness, daytime irritability and dieresis. These effects are normally for relatively high dosages and are not linked with the ingestion of rational amounts of tea (e.g., 1 to10 cups per day) [11].

Methods of preparing green tea infusion vary all over the world, as in China, tea leaves are steeped in hot water having temperature of $70^{\circ} \mathrm{C}$ to $80^{\circ} \mathrm{C}$ for 20 to 40 seconds, and the same tea leaves are usually steeped repeatedly for about seven times. Recently, in Taiwan, particularly in summer seasons, steeping in cold water with the temperature of 4 or $25^{\circ} \mathrm{C}$ is a new popular method for making tea. While in Pakistan, two different methods of green tea preparation are used either adding green tea in boiling water $\left(100^{\circ} \mathrm{C}\right)$ or steeping green tea in warm water $\left(70-80^{\circ} \mathrm{C}\right)$ like Chinese tradition [12]. Different phytochemicals present in green tea are associated with prevention of specific diseases; therefore it is important to consider the preparation method of green tea which generates highest amount of phytochemicals.

Pakistan is the second largest importer of both processed and raw tea from abroad after United Kingdom and the total per capita tea consumption is one $\mathrm{kg}$. There are different kinds of tea and brands of tea offered in the markets of Pakistan having great distinction in their quality, composition and characteristics [13].

In this project, three different brands of green tea which differ greatly in their market prices were selected and analyzed for their antioxidant effects. To the best of our knowledge, no work has been reported in literature where ten different brewing methods of green tea are compared and analyzed. This is the first novel report where different tea brands available in Pakistan have been compared in terms of difference in price and respective health benefits (antioxidants). This project also spots the best green tea (on the basis of price, brewing method and antioxidant potential) among different types of green tea highly consumed in Pakistan.

\section{MATERIALS AND METHODS}

Different types of green tea with two different batches (consignment produced by industries at two different durations) were collected from different markets of Rawalpindi, Pakistan. Green tea of international brand twining of London (ToL - Brand A) was purchased from Cosmo Jinnah Park Rawalpindi. Lipton (Brand B) green tea was collected from Central Store Department Rawalpindi and, low-priced, non-branded open green tea imported from China named as 'China Plando' was collected from Raja bazaar Rawalpindi. Three samples from each batch were prepared by ten different recipes and were analyzed for antioxidant potential.

\subsection{Green Tea Sample Preparation Recipes}

In order to find out the best brewing method, we prepared green tea infusions by ten different recipes. These recipes are used in different cultures throughout the world [11].

\subsubsection{Soft infusion}

In this preparation method, a tea bag was dipped in warm water having the temperature of $75-85^{\circ} \mathrm{C}$ for 3 to 5 minutes. This method is used by Chinese people for tea preparation.

\subsubsection{Hard infusion}

In this brewing method, a tea bag was infused in distilled warm water having the temperature of $75-85{ }^{\circ} \mathrm{C}$ for 25 to 30 minutes.

\subsubsection{Ambient infusion}

This method involves dipping of tea bags in distilled water at room temperature $25 \pm 2{ }^{\circ} \mathrm{C}$ for 30 to 40 minutes.

\subsubsection{Cold infusion}

In this method, tea bags were infused in distilled water and maintained at room temperature for 15 minutes. After that, the prepared infusion was refrigerated for an hour.

\subsubsection{Decoction method}

In this recipe, tea bags or tea leaves are placed in distilled water and boiled for 3 to 5 minutes. The above mentioned five methods are predominantly used in Asian cultures as in Pakistan, China, India and Bangladesh.

\subsubsection{Chilled green tea}

In this type of preparation, tea bags were infused into distilled boiling water for 3 to 5 minutes and after that the infusion was refrigerated for an hour.

\subsubsection{Cold cocktail}

In this alcoholic infusion, distilled water and ethanol was used with the ratio of 60 to $40 \%$. Tea bags were infused in alcoholic solution for 15 minutes and then removed, after which the infusion was refrigerated for an hour.

\subsubsection{Hot Cocktail}

Tea bags were infused in alcoholic solution for 15 minutes followed by heating up to $52{ }^{\circ} \mathrm{C}$. Hot and $\mathrm{CCs}$ are commonly used in Western cultures and in some Asian countries like China and India.

\subsubsection{Puree}

In this recipe, the tea was grounded into fine powder and blended into warm water having the temperature of 70 to $80^{\circ} \mathrm{C}$ for 4 to 5 minutes. The puree obtained was filtered and analysed 
immediately for antioxidant activity. This type of preparation method is mostly used in Japan.

\subsubsection{Sun green tea}

In this method, tea bags are infused in distilled water and put into direct sun light for 3 to 4 hours. This brewing method is most common in United States.

All Green tea samples were prepared in glass beakers of $250 \mathrm{ml}$. Infusions were prepared in distilled water and ethanol. Composition of all tea infusions include one tea bag $(1.265 \mathrm{~g}$ of tea) in $100 \mathrm{ml}$ of distilled water.

\subsection{Antioxidant assays}

\subsubsection{DPPH(1,1-Diphenyl-2-picrylhydrazyl) radical scavenging} assay

As reported [14], reaction mixture consisted of $3 \mathrm{ml}$ of methanol, $0.5 \mathrm{ml}$ of tea infusion, and $0.3 \mathrm{ml}$ of DPPH $(1,1-$ Diphenyl-2-picrylhydrazyl) solution $(0.5 \mathrm{mM})$ in methanol. Reaction mixture was incubated for 45 minutes, after which absorbance was determined by spectrophotometer at $517 \mathrm{~nm}$. Ascorbic acid $(100 \mu \mathrm{g} / \mathrm{ml})$ was used as positive control. Blank sample was methanol and mixture of methanol $(3 \mathrm{ml})$ and DPPH solution $(0.3 \mathrm{ml})$ was taken as negative control. The experiment was performed in triplicates. Percentage of inhibition was determined by using the formula.

Inhibition

$\%=\mathrm{Ac}-\mathrm{As} / \mathrm{Ac} \times 100$

Where

$\mathrm{Ac}=$ Absorbance of the control

As $=$ Absorbance of the sample

\subsubsection{Reducing power Assay}

As reported [15] $2.5 \mathrm{ml}$ of tea infusions was mixed with phosphate buffer of $2.5 \mathrm{ml}(\mathrm{pH} 6.6,0.2 \mathrm{M})$ and $2.5 \mathrm{ml}$ of one percent potassium ferricyanide. The reaction mixture was incubated for about twenty minute at $50^{\circ} \mathrm{C}$. After that, $2.5 \mathrm{ml}$ of ten percent trichloro acetic acid was introduced. $2.5 \mathrm{ml}$ of the reaction mixture was mixed with $2.5 \mathrm{ml}$ of distilled water and $0.5 \mathrm{ml}$ of ferric chloride $(0.1 \%)$. Reaction mixture without tea infusions was used as negative control. Ascorbic acid (1\%) was used as positive control. The absorbance of solution was measured at $700 \mathrm{~nm}$. The experiment was performed in triplicates.

\subsubsection{Phytochemical Analysis}

Qualitative phytochemical examinations were carried out as per the standard methods [16][8].

\subsection{Hager's reagent test}

Infusions were mixed separately into hydrochloric acid (dilute) followed by filtration. After that Hager's reagent test was performed in which filtrates were mixed with Hager's reagent which is the saturated picric acid solution. Existence of alkaloids was indicated by the development of yellow coloured precipitate.

\subsection{Detection of flavonoids}

Infusions were treated by few drops of lead acetate solution. Configuration of yellow colour precipitate showed the existence of flavonoids.

\subsection{Xanthoproteic test}

In this test the extracts were treated with few drops of concentrated nitric acid. Presence of yellow colour indicated the occurrence of proteins.

\subsection{Salkowski's test}

Here infusions were mixed with chloroform and filtered. Then the filtrates were mixed with few drops of concentrated sulphuric acid, shaken and allowed to stand. Appearance of golden yellow colour showed the presence of steroids.

\subsection{Gallic tannin test}

In this test $0.5 \mathrm{ml}$ of tea infusion was dissolved in $1 \mathrm{ml}$ of water, mixed uniformly and then 2 drops of ferric chloride solution were added. Appearance of blue colour indicated the presence of Gallic tannin.

\subsection{Catecholic tannin test}

$0.5 \mathrm{ml}$ of tea extract was dissolved in $1 \mathrm{ml}$ of water, treated consistently then 2 drops of solution of ferric chloride were added. Green black colour was appeared for presence of catecholic tannin.

\subsection{Saponins Test}

Tea infusions $(5 \mathrm{ml})$ were shaken strongly in the company of distilled water $(5 \mathrm{ml})$ in a test tube. The development of steady foam was indicated as a sign of the occurrence of saponins.

\subsection{Detection of Phenols}

Ferric Chloride Test: Tea infusions were mixed with 3-4 drops of ferric chloride solution. Creation of bluish black colour indicated the presence of phenols.

\subsection{Statistical analysis:}

All the experiments were carried out in triplicates. The values were expressed as the means \pm standard deviation (S.D.) of three observations in each group. Two-way ANOVA tests were performed using data analysis tools in excel for calculating $\mathrm{P}$ value. $\mathrm{P}$ value less than or equal to 0.05 was considered to be significant.

\section{RESULTS}

Antioxidant potential of three different types of green tea Brand A, Band non-branded green tea according to ten different brewing methods was successfully screened. The antioxidant potential of different green tea varies and variation occurred from batch to batch of same green tea with the change of brewing 
methods and type of tea. All brewing methods showed considerable percentage inhibition ranging from 58 to $85 \%$ in brand $\mathrm{B}$ green tea. Cold cocktail showed maximum percentage inhibition $(85.5 \% \pm 0.22)$ while minimum percentage inhibition $(58.4 \% \pm 1.19)$ was shown by hard infusion method just like Brand A. Percentage inhibition of brand B green tea varies with brewing method in the following order as; cold cocktail > hard cocktail > sun green tea $>$ cold infusion $>$ Ambient $>$ Puree $>$ Chilled $>$ soft infusion $>$ decoction $>$ hard infusion. The antioxidant activities alter between two batches of brand B green tea in all the brewing methods and this fluctuation in percentage inhibition ranges from 1 to $5 \%$. In case of Brand A, all brewing methods of the selected Brand A showed significant percentage inhibition ranging from 59 to $85 \%$. Cold cocktail showed maximum percentage inhibition $(85.9 \% \pm 1.1)$ while minimum percentage inhibition $(59.9 \% \pm 5.1)$ was shown by hard infusion method. Antioxidant potential of Brand A green tea varies with brewing method in the following order cold cocktail $>$ hard cocktail $>$ ambient infusion $>$ sun green tea $>$ puree > cold infusion > chilled > decoction > soft infusion $>$ hard infusion. Antioxidant variations were also observed between two batches of green tea in all the brewing methods and this fluctuation in percentage inhibition ranges from 1 to $4 \%$.
Non-branded green tea brewing methods also showed significant percentage inhibition ranging from 66 to $84 \%$. Cold cocktail showed maximum percentage inhibition $(84.4 \% \pm 0.42)$ while minimum percentage inhibition $(66.6 \% \pm 0.3)$ was shown by hard infusion method. Percentage inhibition of Non-branded green tea varies with brewing method in the following order as; cold cocktail $>$ hot cocktail $>$ cold infusion $>$ Ambient $>$ sun green tea $>$ Puree $>$ soft infusion $>$ decoction $>$ chilled $>$ hard infusion. All the Percentage inhibitions of green tea infusions calculated by DPPH assay are shown in table 1 . Significant difference $(<0.05)$ was found to be present amongst the tea samples, tea brewing methods and interaction between tea samples and brewing methods as shown in table 4 (a). Reducing power method was also used for measuring antioxidant activities of the tea samples as shown in table 2. Data obtained from reducing power collaborated with the DPPH assay. Higher absorbance values indicate higher reducing ability. Reducing power showed reducing ability of different tea brands with identifying the best brewing method as the cold cocktail (3.885 \pm 0.19 as highest absorbance value) and hard infusion method $(2.890 \pm 0.1$ lowest absorbance value $)$ as the lowest brewing method. Two-way ANOVA depicted significant difference $(<0.05)$ amongst tea brewing method as shown in table 4 (b).

Table 1: DPPH free radical scavenging assay for different brands and preparation methods of green tea.

\begin{tabular}{|c|c|c|c|c|c|c|c|c|c|c|}
\hline \multirow{2}{*}{$\begin{array}{c}\text { Brewing } \\
\text { method } \\
\text { Tea } \\
\text { types }\end{array}$} & \multicolumn{10}{|c|}{ Scavenging activity $(\%)$ of different preparation methods of green tea } \\
\hline & $\begin{array}{c}\text { Soft } \\
\text { infusion }\end{array}$ & $\begin{array}{c}\text { Hard } \\
\text { infusion }\end{array}$ & $\begin{array}{l}\text { Ambient } \\
\text { infusion }\end{array}$ & $\begin{array}{c}\text { Cold } \\
\text { infusion }\end{array}$ & Decoction & $\begin{array}{c}\text { Chilled } \\
\text { green tea }\end{array}$ & $\begin{array}{l}\text { Cold } \\
\text { cocktail }\end{array}$ & $\begin{array}{c}\text { Hot } \\
\text { cocktail }\end{array}$ & Puree & $\begin{array}{c}\text { Sun green } \\
\text { tea }\end{array}$ \\
\hline $\begin{array}{l}\text { Brand B } \\
\text { Batch-1 }\end{array}$ & $70.59 \pm 3.56$ & $\underline{60.29 \pm 0.3}$ & $79.945 \pm 0.39$ & $82.52 \pm 1.73$ & $67.225 \pm 3.05$ & $68.9 \pm 6.09$ & $\mathbf{8 5 . 2 4} \pm 0.14$ & $85.24 \pm 2.98$ & $75.62 \pm 0.70$ & $83.965 \pm 1.52$ \\
\hline $\begin{array}{l}\text { Brand B } \\
\text { Batch-2 }\end{array}$ & $70.59 \pm 2.38$ & $\underline{58.40 \pm 1.19}$ & $82.115 \pm 1.53$ & $81.30 \pm 0$ & $69.615 \pm 1.01$ & $72.725 \pm 2.03$ & $\mathbf{8 5 . 8 4 5} \pm 0.29$ & $84.84 \pm 0.71$ & $80.04 \pm 1.34$ & $85.95 \pm 0.35$ \\
\hline $\begin{array}{l}\text { Brand A } \\
\text { Batch-1 }\end{array}$ & $67.22 \pm 2.08$ & $\underline{62.82 \pm 0.90}$ & $85.01 \pm 0.76$ & $80.625 \pm 0.57$ & $68.42 \pm-3.38$ & $68.66 \pm 1.70$ & $\mathbf{8 5 . 9 4} \pm 1.27$ & $85.04 \pm 1.27$ & $80.995 \pm 0.23$ & $82.27 \pm 0.65$ \\
\hline $\begin{array}{l}\text { Brand A } \\
\text { Batch-2 }\end{array}$ & $66.39 \pm 2.38$ & $\underline{59.87 \pm 5.06}$ & $82.385 \pm 2.68$ & $80.76 \pm 1.15$ & $66.985 \pm 0.67$ & $67.94 \pm 0$ & $\mathbf{8 5 . 9 4 5} \pm 0.86$ & $82.43 \pm 1.56$ & $81.695 \pm 0.53$ & $83.18 \pm 3.68$ \\
\hline $\begin{array}{l}\text { Non-branded } \\
\text { tea }\end{array}$ & $68.07 \pm 0.29$ & $\underline{66.60 \pm 0.3}$ & $79.675 \pm 2.3$ & $81.3 \pm 0.76$ & $66.025 \pm 2.03$ & $66.51 \pm 4.74$ & $\mathbf{8 4 . 4 4} \pm 0.42$ & $83.835 \pm 2.98$ & $36.365 \pm 1.17$ & $78.43 \pm 6.08$ \\
\hline $\begin{array}{l}\text { Ascorbic } \\
\text { Acid }\end{array}$ & \multicolumn{10}{|c|}{$95.25 \pm 2.6$} \\
\hline
\end{tabular}

Bold values indicates the highest antioxidant activity obtained among different types of tea, while underlined values shows lowest antioxidant activity among the tea samples.

Table 2: Reducing power assay for different brands and preparation methods of green tea.

\begin{tabular}{|c|c|c|c|c|c|c|c|c|c|c|}
\hline \multirow{2}{*}{\begin{tabular}{l}
\multicolumn{1}{c}{ Brewing } \\
Methods \\
Type Of \\
Tea \\
\end{tabular}} & \multicolumn{10}{|c|}{ Absorbance values of different type of Green Tea } \\
\hline & $\begin{array}{c}\text { Soft } \\
\text { infusion }\end{array}$ & $\begin{array}{c}\text { Hard } \\
\text { infusion }\end{array}$ & $\begin{array}{l}\text { Ambient } \\
\text { infusion }\end{array}$ & $\begin{array}{c}\text { Cold } \\
\text { infusion }\end{array}$ & Decoction & $\begin{array}{c}\text { Chilled } \\
\text { green tea }\end{array}$ & $\begin{array}{c}\text { Cold } \\
\text { cocktail }\end{array}$ & Hot cocktail & $\begin{array}{c}\text { Green tea } \\
\text { purree }\end{array}$ & $\begin{array}{c}\text { Sun green } \\
\text { tea }\end{array}$ \\
\hline $\begin{array}{l}\text { Brand B } \\
\text { Batch-1 }\end{array}$ & $3.725 \pm 0.39$ & $\underline{2.890 \pm 0.1}$ & $3.742 \pm 0.030$ & $3.154 \pm 0.004$ & $3.597 \pm 0.076$ & $3.715 \pm 0.005$ & $\mathbf{3 . 8 8 5} \pm 0.19$ & $3.757 \pm 0.008$ & $3.489 \pm 0.029$ & $3.603 \pm 0.06$ \\
\hline $\begin{array}{l}\text { Brand B } \\
\text { Batch-2 }\end{array}$ & $3.765 \pm 0.018$ & $\underline{2.960 \pm 0.027}$ & $3.661 \pm 0.05$ & $3.059 \pm 0.03$ & $3.583 \pm 0.027$ & $3.690 \pm 0.06$ & $\mathbf{3 . 8 3 0} \pm 0.018$ & $3.789 \pm 0.07$ & $3.375 \pm 0.033$ & $3.593 \pm 0.011$ \\
\hline $\begin{array}{l}\text { Brand A } \\
\text { Batch-1 }\end{array}$ & $3.70 \pm 0.042$ & $\underline{3.022 \pm 0.032}$ & $3.601 \pm 0.028$ & $3.125 \pm 0.011$ & $3.636 \pm 0.008$ & $3.728 \pm 0.04$ & $\mathbf{3 . 8 0 8} \pm 0.020$ & $3.75 \pm 0.011$ & $3.579 \pm 0.02$ & $3.586 \pm 0.008$ \\
\hline $\begin{array}{l}\text { Brand A } \\
\text { Batch-2 }\end{array}$ & $3.721 \pm 0.036$ & $\underline{2.991 \pm 0.097}$ & $3.695 \pm 0.015$ & $3.133 \pm 0.02$ & $3.661 \pm 0.030$ & $3.639 \pm 0.09$ & $\mathbf{3 . 8 5 2} \pm 0.35$ & $3.725 \pm 0.016$ & $3.429 \pm 0.03$ & $3.599 \pm 0.04$ \\
\hline $\begin{array}{l}\text { Non-branded } \\
\text { tea }\end{array}$ & $3.453 \pm 0.23$ & $\underline{2.978 \pm 0.07}$ & $3.630 \pm 0.0035$ & $3.08 \pm 0.046$ & $3.635 \pm 0.028$ & $3.747 \pm 0.042$ & $\mathbf{3 . 7 9 4} \pm 0.017$ & 3.7440 .014 & $3.488 \pm 0.064$ & $3.556 \pm 0.2$ \\
\hline $\begin{array}{l}\text { Ascorbic } \\
\text { Acid }\end{array}$ & \multicolumn{10}{|c|}{$4 \pm 0.12$} \\
\hline
\end{tabular}

Bold values indicates the highest Absorbance value obtained among different types of tea, while underlined values shows lowest absorbance. 
Table 3: Phytochemical Analysis of different types of green tea.

\begin{tabular}{|c|c|c|c|c|c|c|c|c|c|c|}
\hline \multirow[b]{3}{*}{ Phytochemicals } & \multirow[t]{3}{*}{ Type of tea } & \multirow{2}{*}{\multicolumn{3}{|c|}{$\begin{array}{r}\text { Best brewing Method } \\
\text { Cold cocktail } \\
\end{array}$}} & \multicolumn{3}{|c|}{ Moderate brewing method } & \multirow{2}{*}{\multicolumn{3}{|c|}{$\frac{\text { Lowest Brewing method }}{\text { Hard infusion }}$}} \\
\hline & & & & & \multicolumn{2}{|c|}{ Soft infusion } & \multirow{2}{*}{$\begin{array}{l}\text { Puree } \\
\text { Non-branded tea }\end{array}$} & & & \\
\hline & & Brand B & Brand A & Non-branded Tea & Brand B & Brand A & & \multicolumn{2}{|c|}{\begin{tabular}{cc}
\multicolumn{2}{c}{ Hard infusic } \\
Brand $\mathrm{B}$
\end{tabular}} & $\begin{array}{c}\text { Non-brandec } \\
\text { tea }\end{array}$ \\
\hline Steriods & & ++ & + & - & ++ & ++ & _- & ++ & ++ & - \\
\hline Flavonoids & & ++ & ++ & + & +++ & ++ & ++ & +++ & ++ & ++ \\
\hline Proteins & & +++ & ++ & + & - & - & - & ++ & + & + \\
\hline Catecholictanin & & +++ & ++ & + & + & + & ++ & +++ & ++ & ++ \\
\hline Gallic Tanin & & - & - & - & - & - & - & - & - & _- \\
\hline Saponin & & - & - & - & ++ & +++ & ++++ & - & +++ & +++ \\
\hline Alkoloids & & - & - & - & - & - & - & - & - & - \\
\hline Phenols & & ++++ & +++ & +++ & +++ & + & ++ & ++ & + & + \\
\hline
\end{tabular}

Key: Strongly present (++++), Moderate (+++), Normal (++) Low (+), Not Present (-).

Table 4: Statistical analysis. A-Two-Way ANOVA for Dpph free radical scavenging assay.

\begin{tabular}{|c|c|c|c|c|c|c|}
\hline \multicolumn{7}{|l|}{ ANOVA } \\
\hline Source of Variation & $S S$ & $d f$ & $M S$ & $F$ & $P$-value & F crit \\
\hline Tea Sample & 73.5976 & 4 & 18.3994 & 3.499607 & 0.010203 & 2.462615 \\
\hline Brewing methods & 9902.76 & 9 & 1100.307 & 209.2808 & 0.000000 & 1.974829 \\
\hline Interaction & 451.7109 & 36 & 12.54752 & 2.386567 & 0.000367 & 1.535138 \\
\hline \multicolumn{7}{|c|}{ B-Two-Way ANOVA for reducing power assay } \\
\hline \multicolumn{7}{|l|}{ ANOVA } \\
\hline Source of Variation & SS & $d f$ & $M S$ & $F$ & $P$-value & F crit \\
\hline Tea Sample & 0.045433 & 4 & 0.011358 & 1.285606 & 0.280768 & 2.462615 \\
\hline Brewing methods & 10.72578 & 9 & 1.191753 & 134.8921 & 0.000000 & 1.974829 \\
\hline Interaction & 0.357083 & 36 & 0.009919 & 1.12271 & 0.320495 & 1.535138 \\
\hline
\end{tabular}

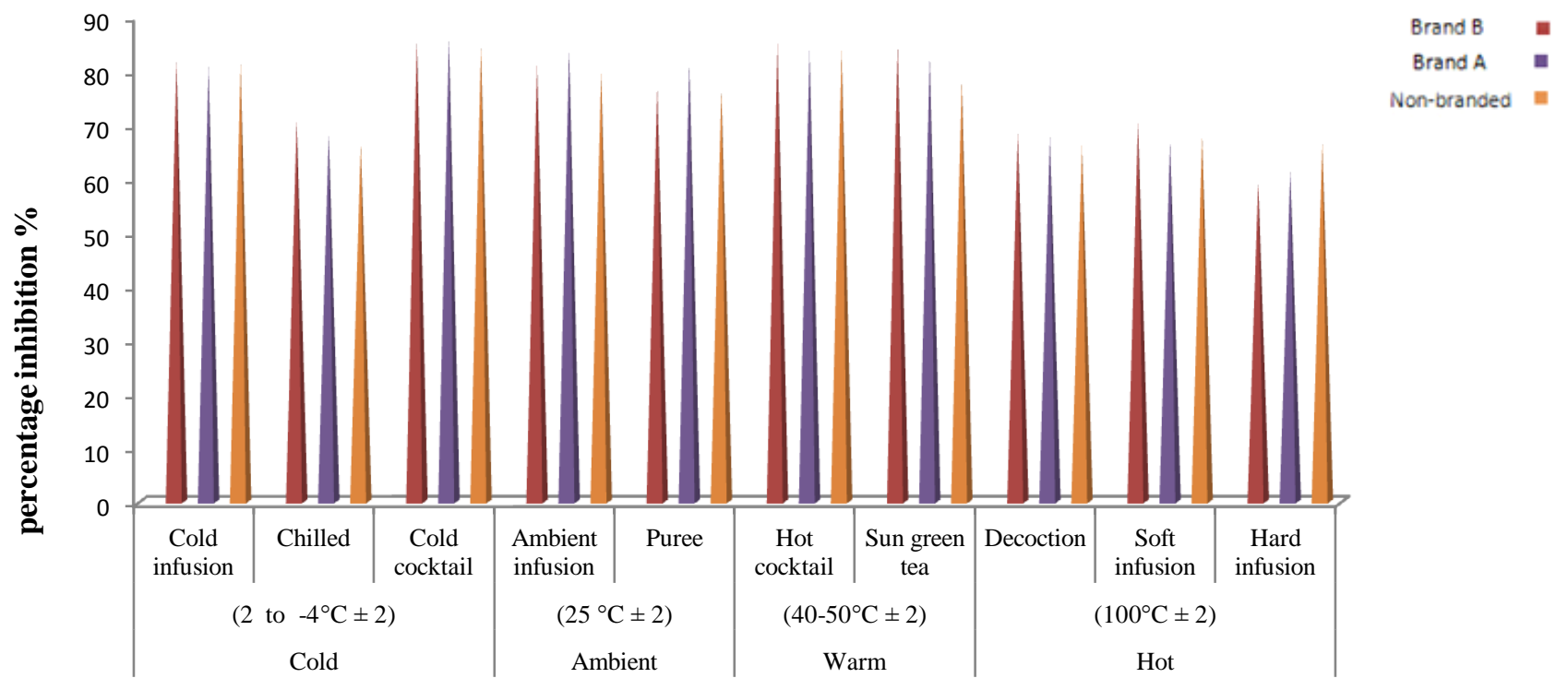

Temperature

Fig.1: Effect of temperature on antioxidant activity of green tea infusions.

\subsection{Effect of temperature on Green Tea}

Temperature had a significant effect on antioxidant activities of green tea. In present research, different brewing methods were investigated out of which three infusion methods were prepared at colder temperatures in the range of 2 to $-4{ }^{\circ} \mathrm{C}$. Other infusions were prepared at ambient, warm and hot temperatures with different ranges. Different brewing methods at ambient and warm temperature showed good antioxidant activities e.g. The antioxidant potential of ambient infusion ranged from 80 to $85 \%$ with sound antioxidant affects in hot cocktail( $85 \%)$ and sun green tea $(84.9 \%)$.

Warm and ambient temperatures are the suitable temperatures identified for extracting antioxidants in green tea by different brewing methods (fig 1). 


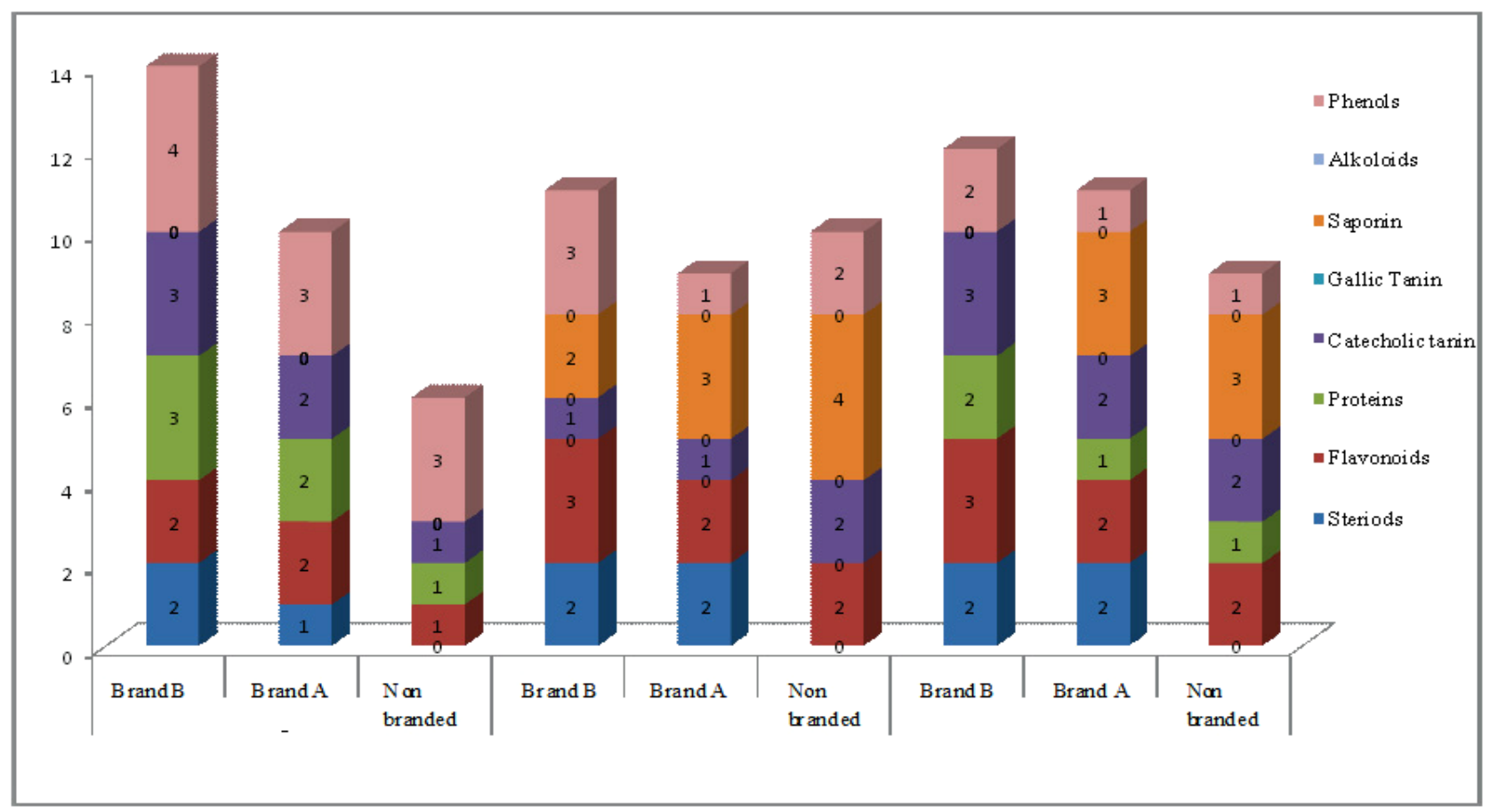

Fig. 2: Phytochemicals of different types of tea in best moderate and lowest brewing Method.

Key $* \quad 0=(-), 1=(+), 2=(++), 3=(+++), 4=(++++)$

\subsection{Phytochemical Investigation}

Three different brewing methods with highest (cold cocktail), lowest (hard infusion) and moderate antioxidant activities (soft infusion and puree) were selected and analyzed for phytochemicals (table 3).

\subsection{Correlation between antioxidant capacity and tea phytoconstituents}

Different brewing methods had different antioxidant properties. The difference in antioxidant properties was due to the difference in phytochemicals released in infusion. The difference in the presence of phytochemical in different brewing methods depends upon steeping time of the infusion, type of tea, type of solvent and temperature. Steeping time of soft infusion was short (3-7minutes) but time of hard infusion was long (30-40 minutes) while temperature and solvent was same in soft and hard infusion. Cold cocktail has low temperature, alcoholic solvent and long steeping time (1 hour). When comparing these three infusions in brand B green tea, we find increased release of phytochemicals in cold cocktail as compared to other counter parts. Similarly, when comparing different tea infusions of Brand A, increased phytochemicals were detected in hard infusion. Non-branded green tea also showed similar results as those of Brand A. Strength of phytochemicals also varies in types of tea and different brewing methods (fig 2).

\section{DISCUSSION}

In Pakistan, due to the numerous medicinal properties of green tea, it is used in all the segments of the society. There are so many brands and types of green tea available in the markets of Pakistan. Out of them, some are imported in raw form and then processed and purchased, like brand B, while some are imported in its final product form and distributed, like Brand A. In this project, we selected three different commonly used brands (with varying prices) of green tea. Brand A is imported through a well-known multinational company (5800 rupees per $\mathrm{kg}$ ), Brand B (2500 rupees per $\mathrm{kg}$ ) is manufactured and distributed by Unilever Pakistan while non-branded green tea (280 rupees per $\mathrm{kg}$ ) is imported from China and distributed in unwrap form. Usage of different types of green varies between different classes of the society based on the prices of green tea. Due to high price, Brand A green tea is used by elate class while Brand B and open nonbranded green tea are mostly used by middle and lower class people of Pakistan. Present research project showed that the difference between antioxidant potential of above mentioned green tea types was very low though they differ greatly in their prices.

Green tea is well known for those individuals that have increased oxidative stress and decreased insulin sensitivity, such as those with the type II diabetes or metabolic syndrome [17]. The opposite association among various serum markers and consumption of green tea indicates that green tea may perform protectively against disorders of the liver and cardiovascular disease and exert protective effects against oxidative stress and cancer[18]. Due to the antioxidant properties of green tea, infusions can be used as defensive method for carcinogenic processes, prostate cancer, liver or renal diseases and many other oxidative damages [19]. Catechins are antioxidants found in green tea that scavenge free radicals [20]. 
Methods of preparing green tea infusion vary all over the world. Iced tea is greatly consumed by Americans who prepare it from hot tea and then cooled with ice. The Japanese frequently make green tea by steeping tea leaves in hot water for about 2 minutes and using them for 2 to 3 times. Actually, tea prepared using cold water contains lower quantity of caffeine, higher aroma and reduced bitterness. For its preparation, tea leaves are steeped in water at $25{ }^{\circ} \mathrm{C}$ for at least 2 hours. Difference is reported between antioxidant activities of tea prepared by different steeping method. Stimulant action of tea is strongest when allowed to steep for 2 to 5 minutes as caffeine dissolves quickly in hot water. Longer steeping of about 10 to20 minutes decreases the stimulant effect and increases the catechin yield as the polyphenols bind the caffeine [11]. Our results also suggest the cold solvent as the best medium for extracting increased antioxidant from green tea. Longer steeping time had no effect on increased antioxidant potential of green tea as indicated in our experiments. Polyphenolic compounds present in tea vary significantly with the source of tea, the production location, the season of tea production, and tea processing, ultimately affecting the antioxidant properties of tea [21]. So, we can say that different brewing methods can also alter the concentration of tea phytochemicals in a ready to drink cup of tea. Green tea of different brand showed higher antioxidant properties in alcoholic cold beverage and lower antioxidant property in hot water (30 to 40 minutes steeping). This is in contrast to the report oriented by some researchers [22] who found higher antioxidant activity for hot water extract of different caffeine products than those of cold extracts and this activity were time and concentration dependent. He found a positive correlation between the antioxidant and reducing compounds presented in water extracts of different caffeine products.

In a comparative research of Korean green tea and traditional fermented Korean tea (TFKT), it was shown that TFKT contains high amount of bioactive compounds and have high antioxidant activity in methanol [23]. In present research, alcoholic brewing method containing 40 percent ethanol also showed higher antioxidant affect than any other type of preparatory method. Moreover, in present study all types of tea showed significant antioxidant properties and content of bioactive compounds so they all could be suggested as a source of bioactive compounds. Herbal infusions of Argentina have been studied for their antioxidant and phenolic content. The elevated correlation between antioxidant capacities of herbal infusions and total phenolic contents suggested that phenolic compounds are the main contributors of antioxidant properties [24]. In our research project, differences between antioxidant properties of various brewing methods were also based on the presence of phenolic compounds. Cold cocktail with highest antioxidant property had higher content of phenols in all three types of tea studied than the other two brewing methods which showed moderate and lowest antioxidant properties. Reduced phenols were detected in the later brewing methods. It was reported that green, black and white tea products that was processed from Japanese and Chinese tea cultivars, had significantly lower antioxidant activity than green tea which was processed from Kenyan tea cultivars [25]. Tea used in present research was purchased from Pakistani markets but they had different origins like China, Kenya, India and Vietnam and were imported to Pakistan. This could be one of the reasons of our selected green tea brands showing different antioxidant potential in different brewing methods.

\section{CONCLUSIONS}

Green tea of three different types used in Pakistan had significant antioxidant potential with Brand A and Brand B almost showing similar performance followed by non-branded green tea. Best brewing recipe was found to be cold cocktail with highest $(85 \%)$ antioxidant potential followed by soft infusion and hard infusion methods which showed moderate $(70 \%)$ and lowest (60\%) antioxidant effects respectively. Phytochemical investigation showed that Brand B tea infusions had higher amount of flavonoids, phenols and Catecholic tannin than Brand A and non-branded green tea. The difference between antioxidant activities of different types of green tea was very slight but the variation in their price was very high. In Pakistan, there is a narrow research related to quality of tea importing from different nations, as the tea consumption is very high, therefore, research should be done related to quality of different types of tea available in markets. Elevated import cost of tea for developing country like Pakistan is very critical; hence there is a need of hour to work on tea to minimize the burden on economy.

\section{REFERENCES}

1. Qadir MFA, Al-Shawi NN. Effects of aqueous green tea extract on ethanol-induced gastric ulcer in rats. Pharmacie Globale International Journal of Comprehensive Pharmacy. 2014; 3: 1-4.

2. Chan EWC, Wong SK. Herbs and herbal teas with antioxidant properties comparable to or superior than those of camellia sinensis. International Journal of Pharmacognosy.2015; 2: 33-37

3. Flayyih MT, Yousif HS Subhi IM. Antimicrobial effects of black tea (Camellia sinensis) on Pseudomonas aeruginosa isolated from eye infection. Iraqi Journal of Science. 2013; 45: 255-265.

4. Ali N, Roshdy E, SabryM, Al-Hendy A.In Green Tea: Varieties, Production and Health Benefits, Ed by W. Wu (p. 34) Nova Science Publishers Inc; 2013.

5. Li P, Huo L, Su W, Lu R, Deng C, Liu L, He C. Free radicalscavenging capacity, antioxidant activity and phenolic content of Pouzolzia zeylanica. Journal of the Serbian Chemical Society. 2011; 76(5): 709-717

6. Jain A, Ojha V, Kumar G, Karthik L, Rao KVB. Phytochemical composition and antioxidant activity of methanolic extract of Ficus benjamina (Moraceae) leaves. Research Journal of Pharmacy and Technology. 2013; 6(11): 1184-1189.

7. Yashin A, Yashin Y, Nemzer B. Determination of antioxidant activity in tea extracts, and their total antioxidant content. American Journal of Biomedical Sciences.2011; 3(4): 322-335.

8. Jang HD, Chang KS, Huang YS, Hsu CL, Lee SH, Su MS. Principal phenolic phytochemicals and antioxidant activities of three Chinese medicinal plants. Food Chemistry. 2007; 103:749-756.

9. Tariq AL, Reyaz AL. Phytochemical analysis of Camellia sinensis Leaves. International Journal of Drug Development and Research. 2012; 4: 311-316.

10. Balsaraf S, Chole R. Green tea: its potential health implications and other benefits. International Journal of Nutrition, Pharmacology, Neurological Diseases. 2015; 5: 46- 49. 
11. Preedy V.R. (Ed.) Tea in Health and Disease Prevention. (pp19-30) Academic Press; 2012.

12. Venditti E, Bacchetti T, Tiano L, Carloni P, Greci L, Damiani E. Hot vs. cold water steeping of different teas: do they affect antioxidant activity? Food Chemistry. 2010; 119:1597-1604.

13. Adnan M, Ahmed A, Khalid N, Hayat I, Ahmed I. Chemical composition and sensory evaluation of tea (Camellia sinensis) commercialized in Pakistan. Pakistan Journal of Botany. 2013; 45: 901-907.

14. Moraes-de-Souza RA, Oldoni TLC, Regitano-d'Arce MAB, Alencar SM. Antioxidant activity and phenolic composition of herbal infusions consumed in Brazil. Ciencia Y. Technolgia Alimentaria. 2008; 6:4147.

15. Raghavendra M, Reddy AM, Yadav PR, Raju AS Kumar LS. Comparative studies on the in vitro antioxidant properties of methanolic leafy extracts from six edible leafy vegetables of India. Asian Journal of Pharmaceutical and Clinical Research.2013; 6: 96-99.

16. Tiwari P, Kumar B, Kaur M, Kaur G, Kaur H. Phytochemical screening and extraction: a review. Internationale Pharmaceutica Sciencia. 2011; 1: 98-106.

17. Hininger-Favier I, Benaraba R, Coves S, Anderson RA, Roussel AM. Green tea extract decreases oxidative stress and improves insulin sensitivity in an animal model of insulin resistance, the fructose-fed rat. The Journal of the American College of Nutrition.2009; 28: 355 361.

18. Tao L, Forester SC, Lambert JD. The role of reactive oxygen species in (-)-epigallocatechin-3-gallat (EGCG)-induced cell growth inhibition and apoptosis in oral cancer cells. Cancer Research. 2012; 72: 54365436.

19. Armoskaite V, Ramanauskiene K, Maruska A, Razukas A, Dagilyte A, Baranauskas A, Briedis V. The analysis of quality and antioxidant activity of green tea extracts. Journal of Medicinal Plants Research. 2011; 5: 811-816.
20. Tran J. Green tea: a potential alternative anti-infectious agent catechins and viral infections. Advances in Anthropology. 2013; 3: 198-202.

21. Kaur L, Jayasekera S, Moughan PJ. In Antioxidant Quality of Tea (Camellia sinensis) as Affected by Environmental Factors. Ed. By V. Preedy, (p121) Academic Press; 2014.

22. Afify M, Shalaby EA, El-Beltagi HS. Antioxidant activity of aqueous extracts of different caffeine products. Notulae Botanicae Horti Agrobotanici Cluj-Napoca.2011; 39: 117-123.

23. Park YS, Lee MK, Heo BG, Ham KS, Kang SG, Cho JY, Gorinstein $\mathrm{S}$. Comparison of the nutrient and chemical contents of traditional Korean Chungtaejeon and green teas. Plant Foods for Human Nutrition.2010; 65: 186-191.

24. Vaquero MJR, Serravalle LT, De-Nadra MM, De-Saad AS Antioxidant capacity and antibacterial activity of phenolic compounds from Argentinean herbs infusions. Food Control,2010; 21: 779-785.

25. Karori SM, Wachira FN, Wanyoko JK. Ngure RM. Antioxidant capacity of different types of tea products. African Journal of Biotechnology. 2007; 6: 2287-2296.

\section{How to cite this article:}

Safdar N, Sarfaraz A, Kazmi Z, Yasmin A. Ten different brewing methods of green tea: comparative antioxidant study. J App Biol Biotech. 2016; 4 (03): 033-040. DOI: 10.7324/JABB.2016.40306 